Agrotrópica 32(2): 85 - 96. 2020.

Centro de Pesquisas do Cacau, Ilhéus, Bahia, Brasil

\title{
CORTICOLOUS AND SAXICOLOUS LICHENS IN BELVEDERE PARK, PAULO AFONSO, BAHIA STATE, BRAZIL: NEW OCCURRENCE RECORDS
}

\author{
Emanuela de Almeida Secunda, Nadja Santos Vitória \\ Universidade do Estado da Bahia, Campus VIII, Departamento de Educação, Colegiado de Biologia, Rua do Gangorra, 503, \\ 48608-240, Bairro Alves de Souza, Paulo Afonso, Bahia, Brasil. emanuela.secunda@ gmail.com
}

\begin{abstract}
Lichens are a diverse and complex group that can inhabit a wide variety of substrates. Taxonomic research of lichenized mycota are still very infrequent, although they are of significant relevance as indicators of mycodiversity. In order to fill that gap, this present research aimed to identify the corticicolus and saxixolous lichens found in Belvedere Park in the municipality of Paulo Afonso, Bahia State, Brazil. Specimens were collected from September/ 2017 through February/2018 on rocks and botanical substrates Cereus jamacaru DC. (mandacaru), Eugenia uniflora L. (pitanga), Licania tomentosa (Benth.) Fritsch (oiti), Mangifera indica L. (manga) and Mauritia flexuosa L.f. (buriti). The morphological features were examined macro and microscopically and identified based on the specialized literature. A total of 22 taxa were identified belonging to the genera Arthonia, Bacidia, Caloplaca, Chrysothrix, Diplotomma, Dirinaria, Haematomma, Lecanora, Parmotrema, Pertusaria, Pyxine e Xanthoparmelia. The lichens found and identified expand knowledge about the distribution data, introducing new fungal botanical hosts for science.
\end{abstract}

Key words: Diversity, taxonomy, caatinga, ecology.

Liquens corticícolas e saxícolas do Parque Belvedere, Paulo Afonso, Bahia, Brasil: novos registros de ocorrência. Os liquens compreendem um grupo diverso e complexo, habitando substratos distintos. Pesquisas taxonômicas da micota liquênica ainda são escassas, mas de grande relevância pois evidenciam a micodiversidade. A fim de suprir essa lacuna, esta pesquisa objetivou identificar os liquens corticícolas e saxícolas encontrados no Parque Belvedere, munícipio de Paulo Afonso, Bahia. Foram coletadas amostras no período de setembro/2017 a fevereiro/2018 em rochas e nos substratos botânicos Cereus jamacaru DC. (mandacaru), Eugenia uniflora L. (pitanga), Licania tomentosa (Benth.) Fritsch (oiti), Mangifera indica L. (manga) e Mauritia flexuosa L.f. (buriti). As características morfológicas foram examinadas macro e microscopicamente e identificadas com base nas literaturas especializadas. Foram identificados 22 táxons pertencentes aos gêneros Arthonia, Bacidia, Caloplaca, Chrysothrix, Diplotomma, Dirinaria, Haematomma, Lecanora, Parmotrema, Pertusaria, Pyxine e Xanthoparmelia. Os liquens encontrados e identificados ampliam o conhecimento sobre os dados de distribuição, apresentando novos hospedeiros botânicos dos fungos para a Ciência.

Palavras-chave: Diversidade, taxonomia, caatinga, ecologia. 


\section{Introduction}

Currently, more than 19.000 lichen species are recognized, representing $17 \%$ of the 110.000 known fungal taxa (Lücking, Hodkinson \& Leavitt, 2016).

The lichenized mycota constitute a diverse and complex group that can colonize a wide range of substrates, including tree trunks and branches, rocks, and other inorganic substrates (Cáceres et al. 2011). They are considered organisms known to be sensitive to environmental disturbances of biotic, abiotic and anthropic nature, being used to assess environmental quality in a specific area by mapping their species (Conti \& Cecchetti, 2001).

Taxonomic and ecological research on lichenized fungi, in general, have been little performed in northeastern Brazil. Cáceres et al. (2014) reported that number of lichen species known for the Sergipe State is 628. Santos et al. (2016) recorded foliicolous lichens occurring in four states in Brazil: Bahia, Sergipe, Paraíba and Pernambuco, totaling 147 species. Santos et al. (2019) documented three new occurrences of lichenized Ascomycota for Bahia State. Aptroot \& Cáceres (2018) described nine new species of lichens for Science found in Bahia. Therefore, due to the lack of surveys of lichenized mycota in the northeast region, the carrying out of inventories is necessary.

The substrate type on which a lichenized fungus develops is important to their identification, and those organisms can be saxicolous (growing on rocks) or corticolous (growing on tree bark). Saxicolous lichens have unique roles in the environment, and help decompose rocks, create organic substrates, prepare and enrich the soil for eventual habitation by other organisms, and provide humidity and essential nutrients (Silva, 2006). Environmental factors such as light and humidity can influence the disposition of corticolous lichens along and around the trunks (Ellis, 2012). The characteristics such as texture, water retention, hardness, $\mathrm{pH}$ and availability of macro and micronutrients of the bark of the host trees are important for the installation of the species (Seaward, 2008).

In Bahia State, Paulo Afonso is a municipality located in Raso da Catarina ecoregion, covering many areas studied by researchers and students, especially in theme of floristics and conservation. Systematized research with lichen taxonomy in region are still scarce, even in face of local diversity.

Much visited by tourists due to its natural attractions, the beautiful squares and parks of Paulo Afonso are part of its history. Belvedere Park is one of the most popular attractions in the municipality. Tree trunks and rocks throughout the park are covered by grayish, greenish, reddish, or yellowish blotches that stimulate the curiosity of attentive visitors. These are lichens, important for the ecosystem and known little by local population.

Urbanization changes the natural environment, causing environmental impacts such as climate change, air pollution and loss of biodiversity (Mckinney, 2006; Lättman et al., 2014; Munzi et al., 2014). Studies show that these changes can gradually modify and decrease the richness of vascular epiphyte species (Becker et al., 2013). It is extremely important to know the diversity of lichens in these areas, as further studies will be able to compare the species richness and report whether the environmental conditions due abiotic and biotic factors have caused some change in the lichen diversity. In order to contribute to expansion of knowledge about lichens, the present research aimed to identify the corticolous and saxicolous lichens found in Belvedere Park. The taxa documented here amplified knowledge of the lichenized mycota in the Raso da Catarina ecoregion, Caatinga Biome, Brazil.

\section{Materials and Methods}

Botanical material was collected in Belvedere Park in the municipality of Paulo Afonso, Bahia State, Brazil, 9 ${ }^{\circ} 23^{\prime \prime} 32^{\prime \prime S}$ and $38^{\circ} 12^{\prime \prime} 30^{\prime \prime} \mathrm{W}$, semi-arid BSh (Koppen) climate, with average rainfall between 500 and 600 milliliters per year (Figure 1). Collected were realized during the period between September/2017 and April/2018. The samples were collected using cutting tools and and held in paper sacks (Kraft-type paper) identified with the host name, locality, and date.

After collecting, the samples were processed, analyzed and identified in the Mycology Laboratory of the Universidade do Estado da Bahia, Campus VIII (UNEB) and subsequently incorporated into the fungal herbarium and fungal culture collection (MICOLAB UNEB VIII). Topographic analyses of the lichens 

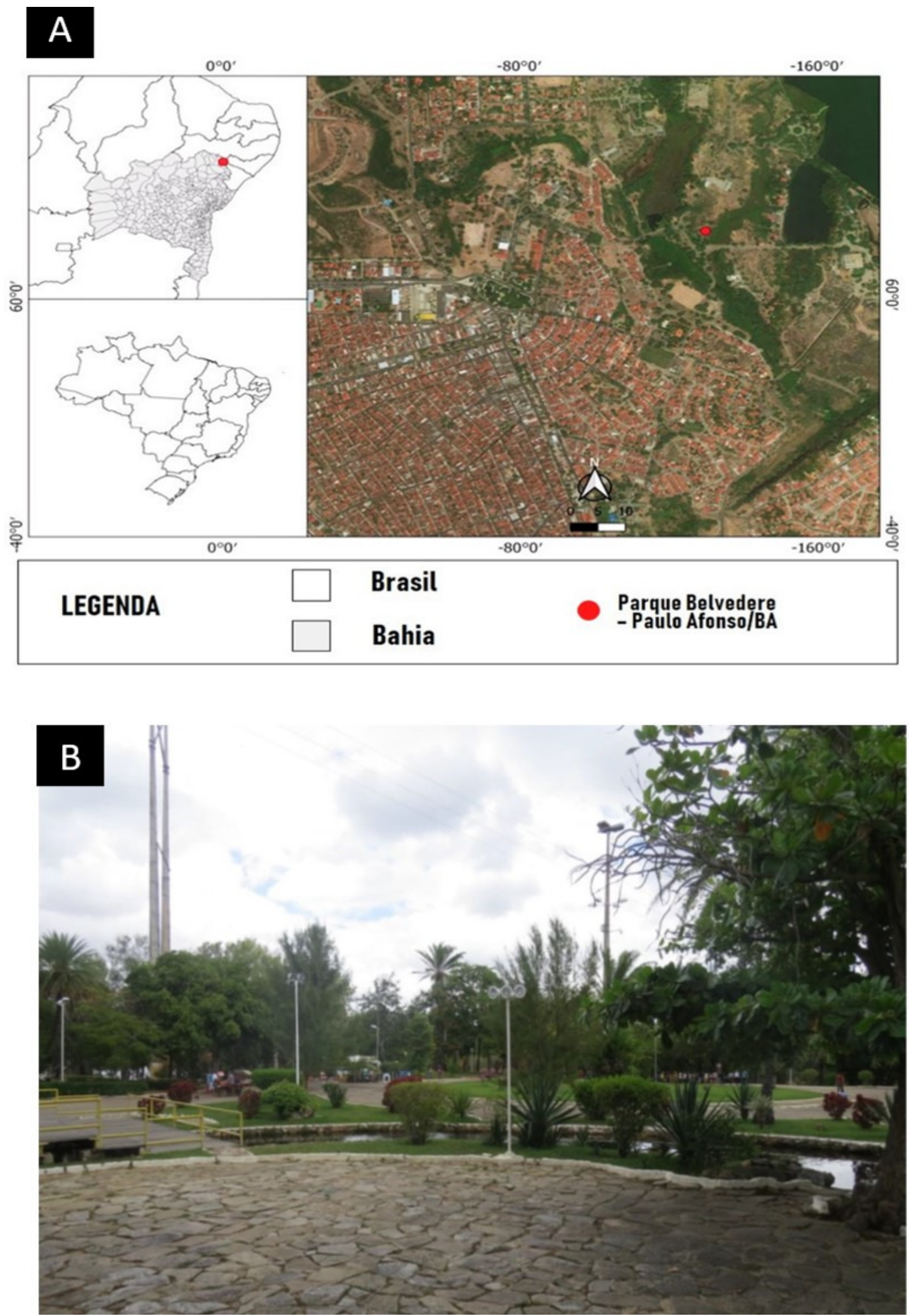

Figure 1. A. Study area location. B. Belvedere Park. Photos: Secunda, E. A. 
were made based on freehand sections. Anatomical and morphological studies of the reproductive and vegetative structures were undertaken with the aid of a visible light stereomicroscope (Zeiss). Slides were prepared using lactophenol, cotton blue stain, Melzer reagent, and a $10 \% \mathrm{KOH}$ solution.

The occurrence records were consulted in speciesLink (2020) database and the fungi were indentified through specialized literature: Cáceres, Lucking \& Rambold (2007); CNALH (2018); Elix (2009); Ekman (1996); Lumbsch \& Elix (2004); Species Fungorum (2020); Kirk, Canon \& David (2001); Kantvilas (2015); Spielmann \& Marcelli (2008); Staiger (2005); Benatti (2013); Jungbluth (2010); Malícek (2014); Rodríguez \& Ortega (2003); Bungartz et al. (2015) and Lucking, Archer \& Aptroot (2009).

\section{Results and Discussion}

A total of 22 taxa were identified belonging to the genera Arthonia, Bacidia, Caloplaca, Chrysothrix,
Diplotomma, Dirinaria, Haematomma, Lecanora, Parmotrema, Pertusaria, Pyxine e Xanthoparmelia. (Table 1). The studied lichens were found in rocks and in following botanical substrates: Cereus jamacaru DC. (mandacaru), Eugenia uniflora L. (pitanga), Licania tomentosa (Benth.) Fritsch (oiti), Mangifera indica L. (manga) e Mauritia flexuosa L.f. (buriti) (Figure 2).

The lichenized Ascomycota examined demonstrated two types of tali/habits: crustose and foliose. The most representative thallus type was crustose comprising $63.63 \%$ of samples (Table 2). Researchers argue that although there is a rich diversity of crustose lichens, there is still little work on them (Käffer et al. 2010). Second Nash (2008), lichens crustose have a great capacity for adaptation, and for this reason they can be found in several terrestrial environments with the most varied environmental conditions, from extremely arid environments such as deserts to Antarctica. Despite the rich diversity, lichens crustose are few studied, mainly due the scarcity of researchers interested in

Table 1. Number of taxa per substrate collected at Belvedere Park, Paulo Afonso-BA

\begin{tabular}{|c|c|c|c|c|c|c|c|}
\hline Taxa & Rock & Mandacaru & Pitanga & Oiti & Manga & Buriti & $\begin{array}{l}\text { Total number } \\
\text { of specimens }\end{array}$ \\
\hline Arthonia sp. & - & $\mathrm{X}$ & - & - & - & - & 01 \\
\hline Bacidia sp. & - & - & $\mathrm{X}$ & - & - & - & 01 \\
\hline Caloplaca sp. & $\mathrm{X}$ & - & - & - & - & - & 01 \\
\hline Caloplaca saxicola & $X$ & - & - & - & - & - & 01 \\
\hline Chrysothrix candelaris & - & - & - & $\mathrm{X}$ & & & 01 \\
\hline Diplotomma sp. & - & - & $\mathrm{X}$ & - & - & - & 01 \\
\hline Dirinaria sp. 1 & - & $\mathrm{X}$ & $\mathrm{X}$ & - & $\mathrm{X}$ & - & 03 \\
\hline Dirinaria sp. 2 & - & - & - & $\mathrm{X}$ & - & - & 01 \\
\hline Dirinaria applanata & $X$ & - & - & - & - & - & 01 \\
\hline Haematomma sp. & $\mathrm{X}$ & - & - & - & - & - & 01 \\
\hline Haematomma persoonii & - & - & - & $X$ & - & - & 01 \\
\hline Lecanora sp. & $\mathrm{X}$ & - & - & - & - & - & 01 \\
\hline Lecanora cf. argentata & $\mathrm{X}$ & - & - & - & - & - & 01 \\
\hline Lecanora cf. helva & - & - & $\mathrm{X}$ & - & - & $\mathrm{X}$ & 02 \\
\hline Lecanora $\mathrm{cf}$. subimmergens & - & - & - & - & $\mathrm{X}$ & - & 01 \\
\hline Parmotrema sp. & - & - & - & $\mathrm{X}$ & - & - & 01 \\
\hline Parmotrema cf. tinctorum & - & - & - & $\mathrm{X}$ & - & - & 01 \\
\hline Pertusaria cf. pertusa & - & - & - & - & - & $\mathrm{X}$ & 01 \\
\hline Pertusaria cf. texana & - & - & $\mathrm{X}$ & & & & 01 \\
\hline Pyxine cf. cocoes & - & - & $\mathrm{X}$ & - & - & - & 01 \\
\hline Pyxine cf. subcinerea & - & - & $\mathrm{X}$ & - & - & - & 01 \\
\hline Xanthoparmelia cf. conspersa & $X$ & - & - & - & - & - & 01 \\
\hline 22 taxa & 07 & 02 & 07 & 05 & 02 & 02 & 25 \\
\hline
\end{tabular}



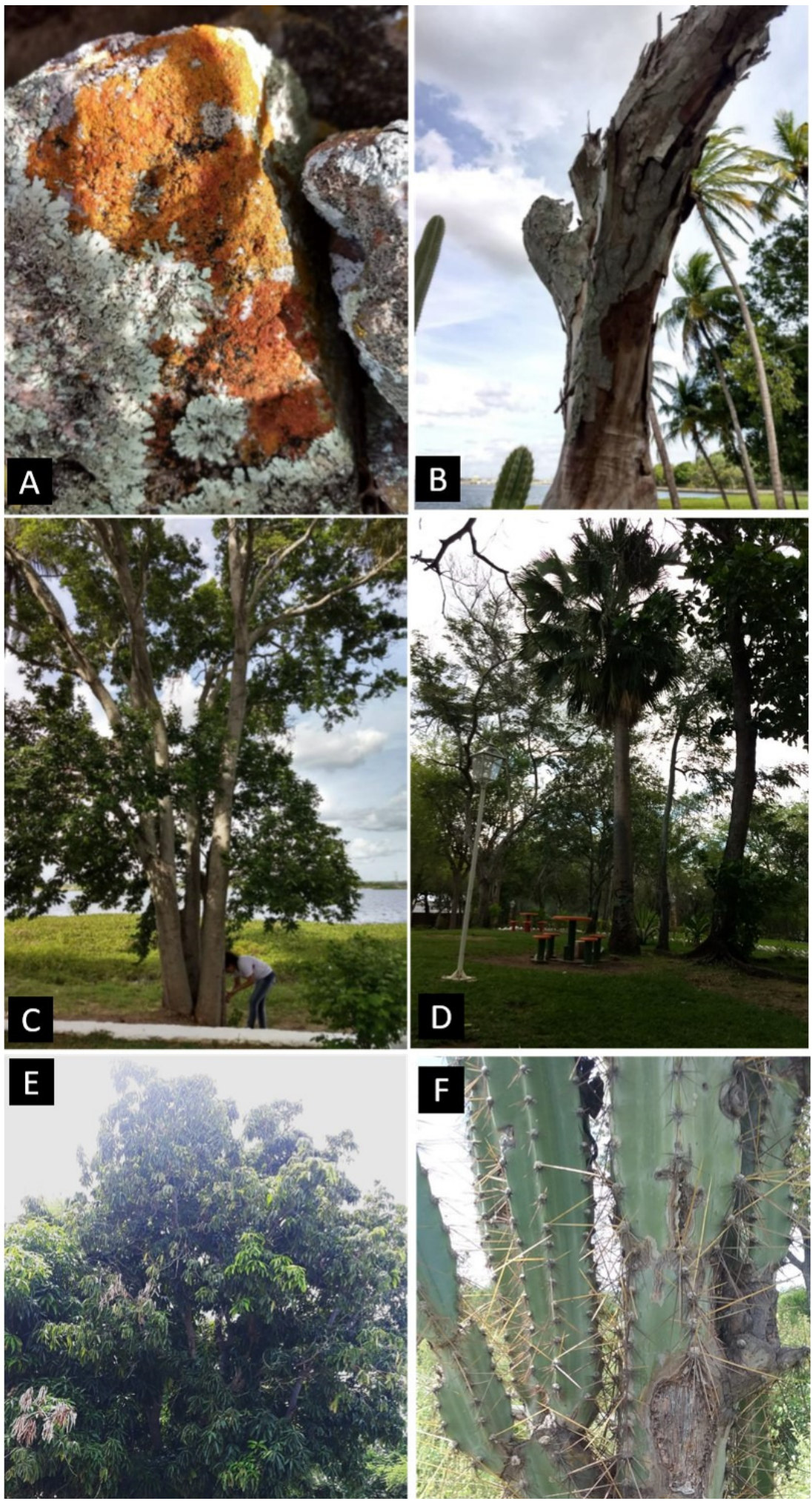

Figure 2. Colonized substrates. A. Rocha. B. Eugenia uniflora (Pitanga). C. Licania tomentosa (Oiti). D. Mauritia flexuosa (Buriti). E. Mangifera indica (manga) F. Cereus jamacaru (mandacaru). Photos: Secunda, E.A. these symbionts and difficult visualization with the naked eye, since they are tiny (Lima, 2013).

According to Cáceres, Lucking \& Rambold (2008), lichens from Caatinga are more adapted to conditions exposed because they are capable of producing secondary cortical substances such as a predominance of atranorin, lychexanthone and other xanthones, as well as derivatives of pulvinic acid and norstictic acid, being less affected by disorders anthropogenic. This study also reports that the type of morphological and anatomical characters may be strictly related to the type of vegetation, being considered as a pre-adaptation.

Table 2. Types of tali/habits of Lichenized Ascomycota examined

\begin{tabular}{lc}
\hline \multicolumn{1}{c}{ Taxa } & Tali/Habits \\
\hline Arthonia sp. & crustose \\
Bacidia sp. & crustose \\
Caloplaca sp. & crustose \\
Caloplaca saxicola & crustose \\
Chrysothrix candelaris & crustose \\
Diplotomma sp. & crustose \\
Dirinaria sp. 1 & foliose \\
Dirinaria sp. 2 & foliose \\
Dirinaria applanata & foliose \\
Haematomma sp. & crustose \\
Haematomma persoonii & crustose \\
Lecanora sp. & crustose \\
Lecanora cf. argentata & crustose \\
Lecanora cf. helva & crustose \\
Lecanora cf. subimmergens & crustose \\
Parmotrema sp. & foliose \\
Parmotrema cf. tinctorum & foliose \\
Pertusaria cf. pertusa & crustose \\
Pertusaria cf. texana & crustose \\
Pyxine cf. cocoes & foliose \\
Pyxine cf. subcinerea & foliose \\
Xanthoparmelia cf. conspersa & foliose \\
\hline
\end{tabular}




\section{Taxonomy}

1. Arthonia sp. (Figure 4A)

Description: Cáceres, Lucking \& Rambold (2007).

Examined material: BRAZIL, BAHIA: municipality of Paulo Afonso, Park Belvedere, trunk of C. jamacaru (mandacaru), 25/04/ 2018, $09^{\circ} 23^{\prime} 47,1^{\prime \prime S}$ and $38^{\circ} 12^{\prime} 41,3^{\prime \prime} \mathrm{O}$, col. Secunda, E. A., Mycology Collection (MICOLAB UNEB VIII 0134).

Note: This genus, is recorded here for the first time on the host $C$. jamacaru (mandacaru) (species Link 2020 database).

2. Bacidia sp. (Figure 4B)

Description: Ekman (1996).

Examined material: BRAZIL, BAHIA: Municipality of Paulo Afonso, Park Belvedere, trunk of E. uniflora (pitanga), 25/04/2018, $09^{\circ} 23^{\prime} 47,1^{\prime \prime S}$ and $38^{\circ} 12^{\prime} 41,3 " \mathrm{\prime \prime}$, col. Secunda, E. A., Mycology Collection (MICOLAB UNEB VIII 0133).

3. Caloplaca sp. (Figure 3A)

Description: Rodríguez \& Ortega (2003); CNALH (2018).

Examined material: BRAZIL, BAHIA: Municipality of Paulo Afonso, Park Belvedere, rock, 21/09/2017, 09 $23^{\prime} 47,1^{\prime \prime S}$ and $38^{\circ} 12^{\prime} 41,3^{\prime \prime} \mathrm{O}$, col. Secunda, E. A., Mycology Collection (MICOLAB UNEB VIII 0120).

4. Caloplaca saxicola (Hoffm.) Nordin (Fig. 3B) Description: CNALH (2018).

Examined material: BRAZIL, BAHIA: Municipality of Paulo Afonso, Park Belvedere, on rock, 21/09/2017, $09^{\circ} 23^{\prime} 47,1^{\prime \prime S}$ and $38^{\circ} 12^{\prime} 41,3^{\prime \prime} \mathrm{O}$, col. Secunda, E. A., Mycology Collection (MICOLAB UNEB VIII 0119).

Note: According to the species Link (2020) database there are no known records for Bahia State.

5. Chrysothrix candelaris (L.) J. R. Laundon., Lichenologist 13(2): 110(1981). (Figure 4C)

Description: Cáceres, Lucking \& Rambold (2007).

Examined material: BRAZIL, BAHIA: Municipality of Paulo Afonso, Park Belvedere, trunk of $L$. tomentosa (oiti), 15/02/2018, 09 $23^{\prime} 47,1^{\prime \prime S}$ and $38^{\circ} 12^{\prime} 41,3 " \mathrm{\prime \prime}$, col. Secunda, E. A., Mycology Collection (MICOLAB UNEB VIII 0136).
Note: This is first record for Bahia State on a new botanical host for science, L. tomentosa (oiti) (species link, 2020 database).

6. Diplotomma sp. (Figure 4D)

Description: Elix (2011).

Examined material: BRAZIL, BAHIA: Municipality of Paulo Afonso, Park Belvedere, on trunk of E. uniflora (pitanga), 25/04/2018, 09 $23^{\circ} 47,1^{\prime \prime S}$ and $38^{\circ} 12^{\prime} 41,3 " \mathrm{O}$, col. Secunda, E.A., Mycology Collection (MICOLAB UNEB VIII 0118).

Note: Eugenia uniflora (pitanga) is recorded here for the first time as a host for this genus (species link, 2020 database).

\section{Dirinaria sp.1 (Figure 4E)}

Description: Elix (2009); Cáceres, Lucking \& Rambold (2007).

Examined material: BRAZIL, BAHIA: Municipality of Paulo Afonso, Park Belvedere, trunk of $M$. indica (manga), 25/04/2018, 09 $23^{\prime} 47,1^{\prime \prime S}$ and $38^{\circ} 12^{\prime} 41,3^{\prime \prime} \mathrm{O}$, col. Secunda, E. A., Mycology Collection (MICOLAB UNEB VIII 0127); trunk of E. uniflora (pitanga), 25/ 04/2018, $09^{\circ} 23^{\prime} 47,1^{\prime \prime} \mathrm{S}$ and $38^{\circ} 12^{\prime} 41,33^{\prime} \mathrm{O}$, col. Secunda, E.A., Mycology Collection (MICOLAB UNEB VIII 0130); trunk of $C$. jamacaru (mandacaru), 25/04/2018, $09^{\circ} 23^{\prime} 47,1^{\prime \prime S}$ and $38^{\circ} 12^{\prime} 41,3^{\prime \prime}$, col. Secunda, E. A., Mycology Collection (MICOLAB UNEB VIII 0132).

8. Dirinaria sp. 2 (Figure 4F)

Description: Elix (2009).

Examined material: BRAZIL, BAHIA: Municipality of Paulo Afonso, Park Belvedere, trunk of L. tomentosa (oiti), 15/02/2018, 09 $23^{\circ} 47,1^{\prime \prime S}$ and $38^{\circ} 12^{\prime} 41,3 " \mathrm{O}$, col. Secunda, E. A., Mycology Collection (MICOLAB UNEB VIII 0137).

Note: Licania tomentosa (oiti) is a host botanical new for the lichen (species link, 2020 database).

9. Dirinaria applanata (Fée) D. D. Awasthi (Figure 3C)

Description: Elix (2009); Cáceres, Lucking \& Rambold (2007).

Examined material: BRAZIL, BAHIA: Municipality of Paulo Afonso, Park Belvedere, on rock, 21/09/2017, $09^{\circ} 23^{\prime} 47,1^{\prime \prime S}$ and $38^{\circ} 12^{\prime} 41,3^{\prime \prime} \mathrm{O}$, col. Secunda, E. A., Mycology Collection (MICOLAB UNEB VIII 0114).

Note: This is the first record for the Bahia State (species link, 2020 database). 
10. Haematomma sp. (Figure 3D)

Description: Elix (2004). Examined material: BRAZIL, BAHIA: Municipality of Paulo Afonso, Park Belvedere, rock, 21/09/ 2017, $09^{\circ} 23^{\prime} 47,1^{\prime \prime S}$ and $38^{\circ} 12^{\prime} 41,3^{\prime \prime} \mathrm{O}$, col. Secunda, E. A., Mycology Collection (MICOLAB UNEB VIII 0123).

11. Haematomma persoonii (Fée) A. Massal.

(Figure 4G)

Description: Elix (2004); Cáceres, Lucking \& Rambold (2007).

\section{Examined material:} BRAZIL,

BAHIA: Municipality of Paulo Afonso, Park Belvedere, trunk of L. tomentosa (oiti), 25/04/2018, 09 $23^{\prime} 47,1^{\prime \prime} \mathrm{S}$ and $38^{\circ} 12^{\prime} 41,3^{\prime \prime} \mathrm{O}$, col. Secunda, E. A., Mycology Collection (MICOLAB UNEB VIII 0126).

Note: Licania tomentosa (oiti) is a host botanical new for the lichen (species link, 2020 database).

\section{Lecanora sp.}

(Figure 3E)

Description: Rodríguez \& Ortega (2003); Cáceres, Lucking \& Rambold (2007).

\section{Examined material:} BRAZIL, B AHIA: Municipality of Paulo Afonso, Park Belvedere, on rock, 21/ 09/2017, 09 $23^{\circ} 47,1^{\prime \prime S}$ and $38^{\circ} 12^{\prime} 41,3^{\prime \prime O}$, col. Secunda, E. A., Mycology Collection (MICOLAB UNEB VIII 0117).
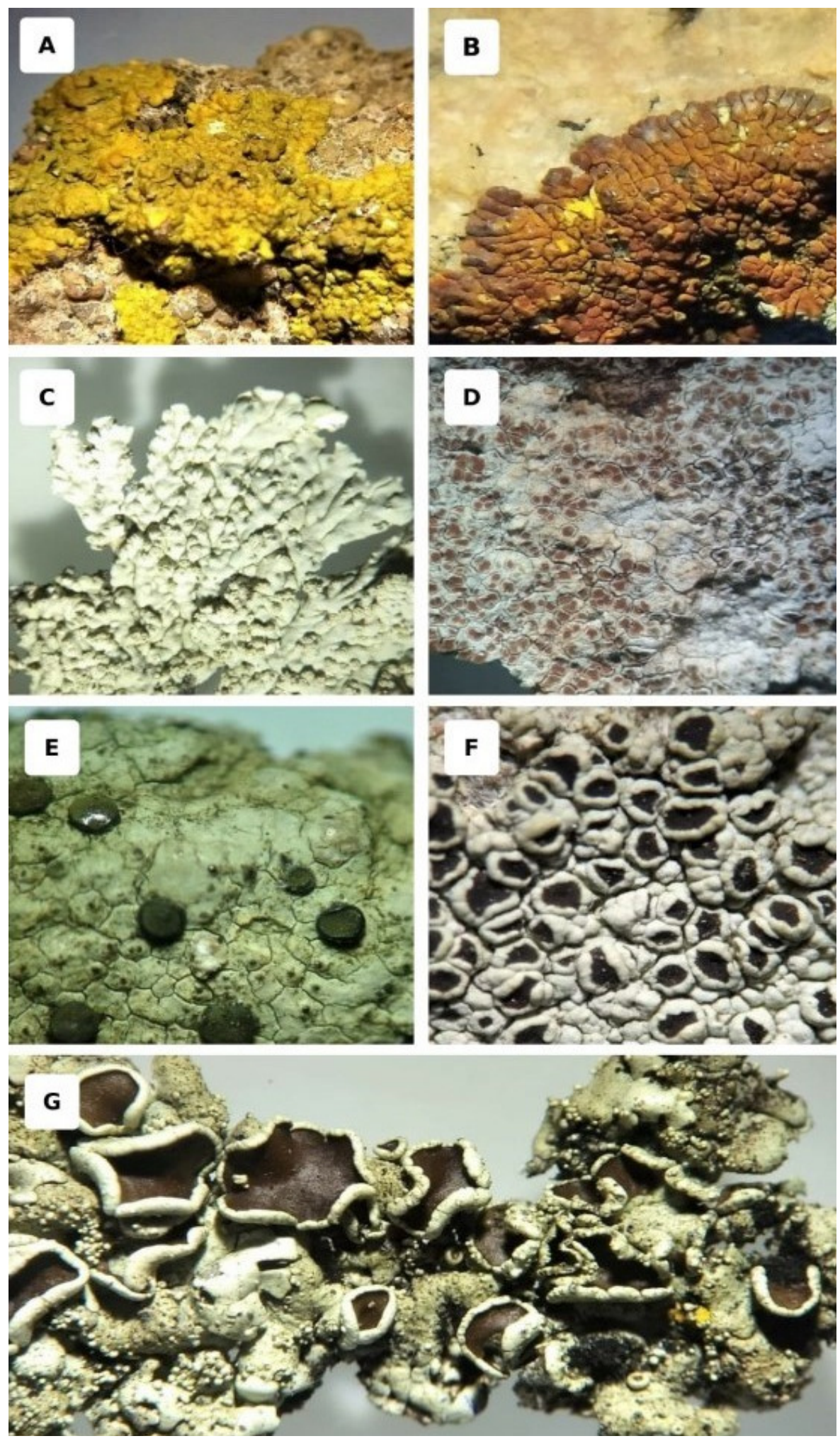

Figure 3. Saxicolous morphospecies: A- Caloplaca sp.; B- C. saxicola; C- Dirinaria applanata; D- Haematomma sp.; E- Lecanora sp.; F- Lecanora cf. argentata; GXanthoparmelia cf. conspersa. Photos: Secunda, E.A. 
13. Lecanora cf. argentata (Ach.) Malme

(Figure 3F)

Description: CNALH (2018); Lumbsch \& Elix (2004).

Examined material: BRAZIL, BAHIA: Municipality of Paulo Afonso, Park Belvedere, on rock, 21/09/201, $09^{\circ} 23^{\prime} 47,1^{\prime \prime S}$ and $38^{\circ} 12^{\prime} 41,3^{\prime \prime} \mathrm{O}$, col. Secunda, E. A., Mycology Collection (MICOLAB UNEB VIII 0116).

Note: There are no previous records of the species on rock substrate. Molecular studies are needed to confirm the species. Morphologically L. argentata was the closest species.

14. Lecanora cf. helva Stizenb. (Figure 4H)

Description: Lumbsch \& Elix (2004); Cáceres, Lucking \& Rambold (2007); CNALH (2018).

Examined material: BRAZIL, BAHIA: Municipality of Paulo Afonso, Park Belvedere, trunk of M. flexuosa (buriti), 15/02/2018, 09 $23^{\circ} 47,1^{\prime \prime} \mathrm{S}$ and $38^{\circ} 12^{\prime} 41,3^{\prime \prime}$ O, col. Secunda, E. A., Mycology Collection (MICOLAB UNEB VIII 0121); trunk of E. uniflora (pitanga), 24/05/2018, 09 $23^{\prime} 47,1^{\prime \prime S}$ and $38^{\circ} 12^{\prime} 41,3^{\prime \prime O}$, col. Secunda, E. A., Mycology Collection (MICOLAB UNEB VIII 0122).

Note: There are no previous records of this fungus colonizing $M$. flexuosa (buriti) and E. uniflora (pitanga) (species link, 2020 database). Molecular studies are needed to confirm the species.

\section{Lecanora cf. submmergens Vain.}

(Figure 5G)

Description: Lumbsch \& Elix (2004).

Examined material: BRAZIL, BAHIA: Municipality of Paulo Afonso, Park Belvedere, trunk of $M$. indica (manga), 15/08/2018, 09 $23^{\prime} 47,1^{\prime \prime S}$ and $38^{\circ} 12^{\prime} 41,3^{\prime \prime} \mathrm{O}$, col. Secunda, E. A. Mycology Collection (MICOLAB UNEB VIII 0125).

Note: There are no previous records of this taxon colonizing $M$. indica (manga) (species link, 2020 database). Molecular studies are needed to confirm the species.

16. Pyxine cf. cocoes (Sw.) Nyl. (Figure 5C)

Description: CNALH (2018).

Examined material: BRAZIL, BAHIA: Municipality of Paulo Afonso, Park Belvedere, trunk de E. uniflora (pitanga), 25/04/2018,09 $23^{\prime} 47,1^{\prime \prime S}$ and $38^{\circ} 12^{\prime} 41,3^{\prime \prime} \mathrm{O}$, col. Secunda, E. A., Mycology Collection (MICOLAB UNEB VIII 0129).

Note: This is the first record of E. uniflora (pitanga) as host for this fungus (species link, 2020 database). Molecular studies are needed to confirm the species.

17. Pyxine cf. subcinerea Stirt. (Figure 5D)

Description: CNALH (2018); Jungbluth (2010).

Examined material: BRAZIL, BAHIA: Municipality of Paulo Afonso, Park Belvedere, trunk of E. uniflora (pitanga), 25/04/2018, 09 $23^{\prime} 47,1^{\prime \prime S}$ and 38 $12^{\prime} 41,3^{\prime \prime O}$, col. Secunda, E. A., Mycology Collection (MICOLAB UNEB VIII 0131).

Note: This is the first record of Eugenia uniflora (pitanga) as a host for this lichen (species link, 2020 database). Molecular studies are needed to confirm the species.

18. Parmotrema sp. (Figure 5E)

Description: Benatti (2013).

Examined material: BRAZIL, BAHIA: Municipality of Paulo Afonso, Park Belvedere, trunk of L. tomentosa (oiti), 15/02/2018, 09 $23^{\circ} 47,1^{\prime \prime S}$ and $38^{\circ} 12^{\prime} 41,3 " \mathrm{O}$, col. Secunda, E. A., Mycology Collection (MICOLAB UNEB VIII 0128).

Note: This genus is recorded here for the first time colonizing L. tomentosa (oiti), (species link, 2020 database).

19. Parmotrema cf. tinctorum (Despr. exNyl.) Hale. (Figure 5F)

Description: Jungbluth (2006); Benatti (2013).

Examined material: BRAZIL, BAHIA: Municipality of Paulo Afonso, Park Belvedere, trunk of L. tomentosa (oiti), 15/02/2018, $09^{\circ} 23^{\prime} 47,1^{\prime \prime S}$ and $38^{\circ} 12^{\prime} 41,3 " \mathrm{O}$, col. Secunda, E. A., Mycology Collection (MICOLAB UNEB VIII 0124).

Note: Parmotrema tinctorum is documented here for the first time colonizing $L$. tomentosa (oiti) (species link, 2020 database). Molecular studies are needed to confirm the species.

20. Pertusaria cf. texana Müll Arg. (Figure 5A) Description: Bungartz et al. (2015).

Examined material: BRAZIL, BAHIA: 
Municipality of Paulo Afonso, Park Belvedere, E. uniflora (pitanga), 25/04/2018, $09^{\circ} 23^{\prime} 47,1^{\prime \prime S}$ and $38^{\circ} 12^{\prime} 41,3^{\prime \prime} \mathrm{O}$, col. Secunda, E. A. Mycology Collection (MICOLAB UNEB VIII 0135).

Note: This is the first record of the species for Brazil and a new botanical host, E. uniflora (pitanga) (species link, 2020 database). Molecular studies are needed to confirm the species.

\section{Pertusaria $c f$. pertusa} (L.) Tuck. (Figure 5B)

Description: Rodríguez \& Ortega (2003).

Examined material: BRAZIL, BAHIA: Municipality of Paulo Afonso, Park Belvedere, on $M$. flexuosa (buriti), 15/02/2018, 09 23'47,1"S and $38^{\circ} 12^{\prime} 41,3^{\prime \prime} \mathrm{O}$, col. Secunda, E. A., Mycology Collection (MICOLAB UNEB VIII 0115).

Note: This is the record first of $\mathrm{P}$. pertusa colonizing $M$. flexuosa (buriti) (species link, 2020 database). Molecular studies are needed to confirm the species.

22. Xanthoparmelia $c f$. conspersa (Ehrh. ExAch.) Hale

(Figure 3G)

Description: Rodríguez \& Ortega (2013); CNALH (2018).

Examined material: BRAZIL, BAHIA: Municipality of Paulo Afonso, Park Belvedere, on rock, 21/09/2017, $09^{\circ} 23^{\prime} 47,1^{\prime \prime S}$ and $38^{\circ} 12^{\prime} 41,3^{\prime \prime} \mathrm{O}$, col. Secunda, E. A., Mycology Collection (MICOLAB UNEB VIII 0113). Molecular studies are needed to confirm the species.
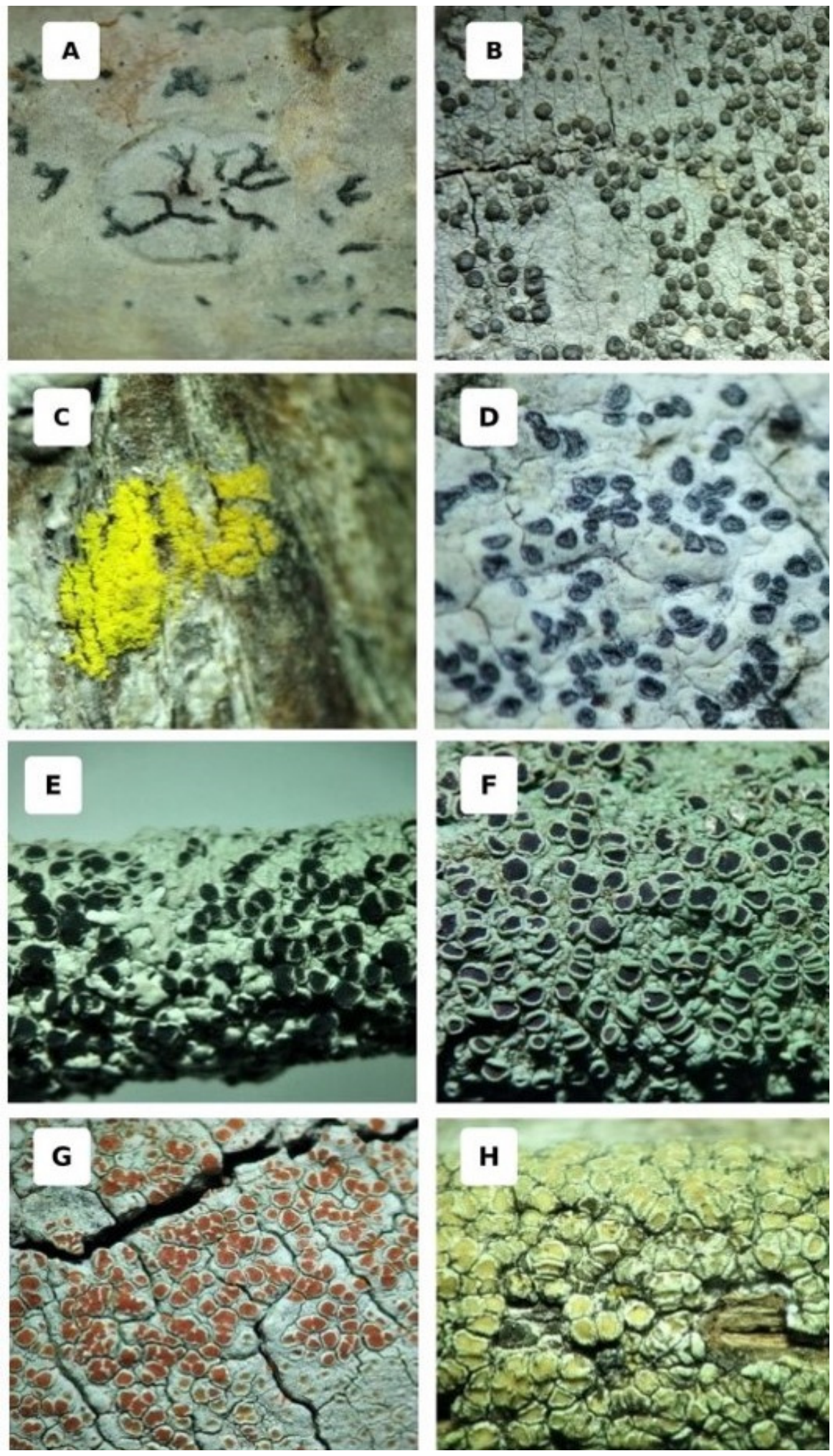

Figure 4. Corticolous morphospecies: A- Arthonia sp.; B- Bacidia sp. C- Chrysothrix candelaris; D- Diplotomma sp.; E- Dirinaria sp.1; F- Dirinaria sp.2; G- Haematoma persoonii; H- Lecanora cf. helva. Photos: Secunda, E.A. 

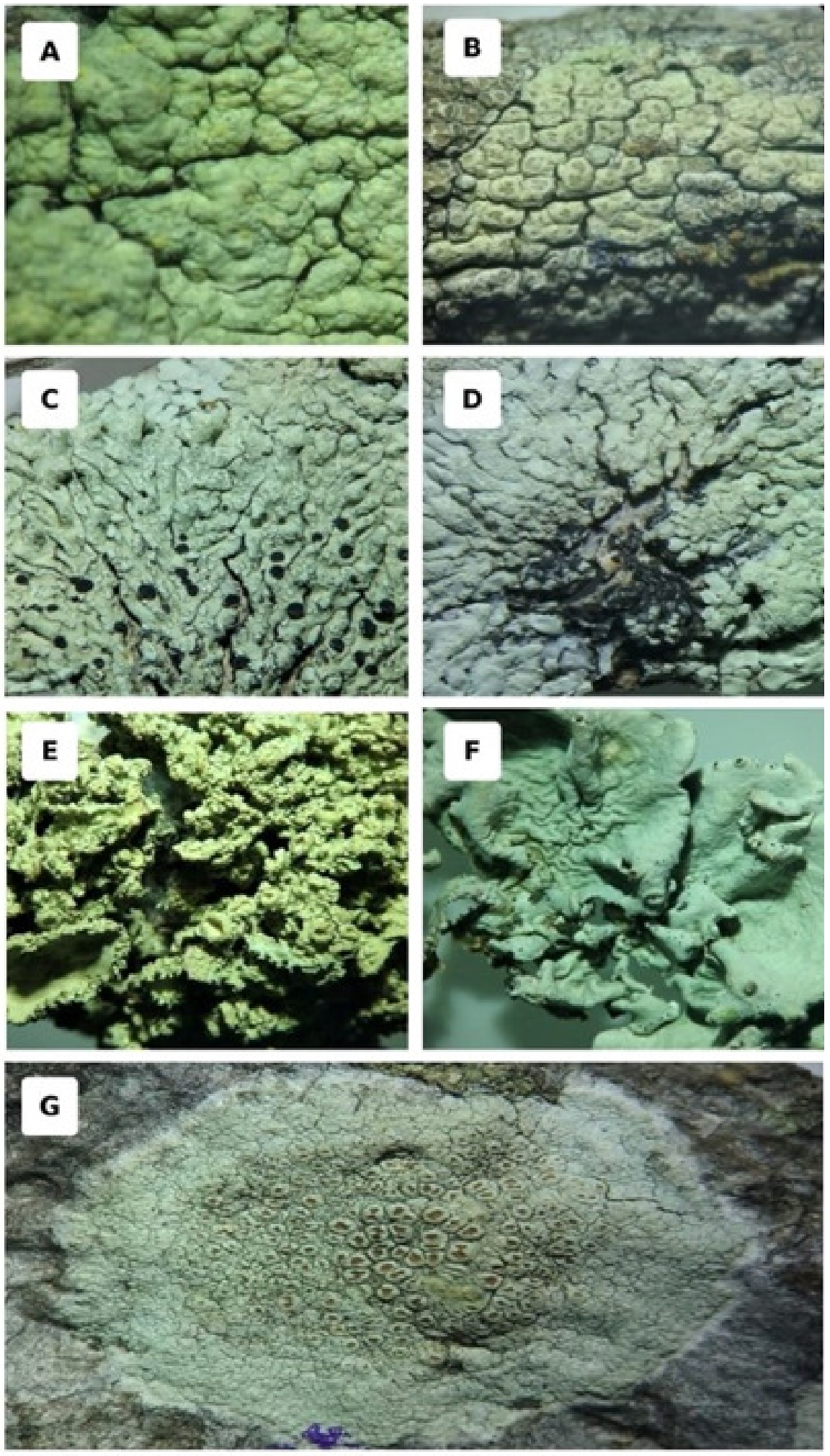

Figure 5. Corticolous morphospecies: A- Pertusaria cf. texana; B - Pertusaria cf. pertusa $; \mathbf{C}$ - Pyxine cf. cocoes; D - Pyxine cf. Subcinerea $; \mathbf{E}$ - Parmotrema sp.; F- Parmotrema cf. tinctorum; G - Lecanora cf. subimmergens. Photos: Secunda, E.A.

\section{Conclusions}

The lichens found and identified expand knowledge about the distribution data, introducing new fungal botanical hosts for science.

Systematic research focusing on the taxonomy and ecology of lichens are necessary and important so they need to be encouraged to train and qualify professionals and students for work with Mycology.

\section{Acknowledgments}

The authors thank the Universidade do Estado da Bahia, Campus VIII (UNEB) for the use of laboratory facilities and equipment there, the Fundação de Amparo à Pesquisa do Estado da Bahia (FAPESB) for opportunity to work as a volunteer in the cientific initiation Program (IC) to the first author and the resource provided for publication by Programa Interno de Auxílio Financeiro à Publicação em Periódicos Nacionais e Internacionais Qualificados para a PósGraduação (PROPUBLIC) and colleagues the Mycology Laboratory at UNEB Maiara Araújo, Rebeca Barbosa and Nilo Fortes for contributions.

\section{Literature Cited}

APTROOT, A.; CÁCERES, M. E. S. 2018. New lichen species from Chapada Diamantina, Bahia, Brazil. The Bryologist 121(1):6779. 
BENATTI, M. N. 2013. Espécies de Parmotrema (Parmeliaceae, Ascomycota) no Parque Estadual da Cantareira, Estado de São Paulo, Brasil I. As espécies com máculas e figuradas ou reticulares. Hoehnea 40:649-659.

BECKER, D. F. P. et al. 2013. Riqueza, estrutura comunitária e distribuição vertical de epífitos vasculares do Parque Natural Municipal Tupancy, Arroio do Sal, RS, Brasil. Botânica 64:127-139.

BUNGARTZ, F. et al. 2015. Endemism in the genus Pertusaria (Pertusariales, lichenized Ascomycota) from the Galapagos Islands. Telopea 18:325-369.

CÁCERES, M. E. S. 2007. Corticolous crustose and microfoliose lichens of northeastern Brazil. IHWVerlag, Eching, Alemanha. Libri Botanici 22:1-168.

CÁCERES, M. E. S.; LÜCKING, R.; RAMBOLD, G. 2008. Corticolous Microlichens in Northeastern Brazil: Habitat Differentiation Between Coastal Mata Atlântica, Caatinga and Brejos de Altitude. The Bryologist 111(1):98-117.

CÁCERES, M. E. S. et al. 2011. New occurrences of corticolous lichens crusts and microfolioses in Caatinga vegetation in the semi-arid region of Alagoas. Acta Botanica Brasilica 25(4):885-889.

CÁCERES, M. E. S. et al. 2014. Liquens brasileiros: novas descobertas evidenciam a riqueza no Norte e Nordeste do país. Boletim do Museu de Biologia Mello Leitão 35:101-119.

CONSORTIUM OF LICHEN HERBARIA NORTH AMERICAN-CNALH. 2018. Available in: $<$ http //: lichenportal.org/portal/index.php $>$. Accessed on july 30, 2018.

CONTI, M. E.; CECCHETTI, G. 2001. Biological monitoring: lichens as bioindicators of air pollution assessment a review. Environmental Pollution 114(3):471-492.

CENTRO DE REFERÊNCIA EM INFORMAÇÃO AMBIENTAL - CRIA. 2020. Specieslink. Database. Available in:<http://www.splink.org.br/ $>$ Accessed on 31 march 2020.

ELIX, J. A. 2004. Haematommataceae. Flora of Australia 56A:4-10.

ELIX, J. A. 2009. Dirinaria, Fl. Australia 57:509-517.
ELIX, J. A. 2011. Diplotomma, Australian Physciaceae (Lichenised Ascomycota). Available in: <http:// www.anbg.gov.au/abrs/lichenlist/ Diplotomma.pdf>. Accessed on: Nov 17, 2018.

ELLIS, C. J. 2012. Lichen epiphyte diversity: A species, community and trait-based review. Perspectives in Plant Ecology, Evolution and Systematics 14:131-152.

EKMAN, S. 1996. The corticolous and lignicolous species of Bacidia and Bacidina in North America. Opera Botanica 127:1-148.

JUNGBLUTH, P. 2006. A família Parmeliaceae (fungos liquenizados) em fragmentos de cerrados do Estado de São Paulo. Tese de Doutorado. Instituto de Botânica, Secretaria do Meio Ambiente, SP. 323p.

JUNGBLUTH, P. 2010. Estudos taxonômicos em Physcia (Schreb.) Michx. e Pyxine Fr. (Physciaceae, Ascomycota). Tese de doutorado. Instituto de Botânica, Secretaria de Estado do Meio Ambiente, SP. 228p.

KÄFFER, M. I. et al. 2010. Novas ocorrências de liquens corticícolas crostosos para a região sul do Brasil. Acta Botânica Brasílica 24(4):948-951.

KANTVILAS, G.; WEDIN, M. 2015. Lichenicolous species of the ascomycete genus Arthonia Ach. From Kangaroo Island. Journal of the Adelaide Botanic Gardens 1-6.

KIRK, P. M.; CANNON, P. F.; DAVID, J. C. 2001. And Stalpers, J.A. Ainsworth \& Bisby's Dictionary of Fungi. 9th Edn. CABI Publishing.

LÄTTMAN, H. et al. 2014. Decline in lichen biodiversity on oak trunks due to urbanization. Nordic Journal of Botany 32:518-528.

LIMA, E L. 2013. Riqueza e composição de liquens corticícolas crostosos em área de Caatinga no Estado de Pernambuco. Dissertação Mestrado. Universidade Federal de Pernambuco, Recife, PE. 109p.

LUMBSCH, H. T.; ELIX, J. 2004. Lecanora. In Flora of Australia 56A (4). CSIRO Publishing.

LÜCKING, R.; HODKINSON, B. P.; LEAVITT, S. D. 2016. The 2016 classification of $1 \mathrm{i}$ c h e n i ze 
fungi in the Ascomycota and BasidiomycotaApproaching one thousand genera.The Bryologist 119(4):361-416.

LÜCKING, R.; ARCHER, A. W.; APTROOT, A. 2009. A world-wide key to the genus Graphis (Ostropales: Graphidaceae). The Lichenologist 41(4):363-452.

MALÍCEK, J. 2014. A revision of the epiphytic species of the Lecanora subfusca group (Lecanoraceae, Ascomycota) in the Czech Republic. The Lichenologist 46(4):489-513.

MCKINNEY, M. L. 2006. Urbanization as a major cause of biotic homogenization. Biological Conservation 127(3):247-260.

MUNZI, S. et al. 2014. Lichens as. ecological indicators in urban areas: beyond the effects of pollutants. Journal of Applied Ecology 51(6):1750-1757.

NASH, T. H. 2008. III. Lichen Biology. Cambridge: Cambridge University Press. 303p.

RODRÍGUEZ, E. B.; PÉREZ-ORTEGA, S. 2003. Liquenes de la reserva Natural Integral de Muniellos, Asturias, KRK Ediciones.

SANTOS M. A. L.; VITÓRIA N. S.; BEZERRA, J. L. 2016. Fungos Colonizando Palmeiras em Áreas de Caatinga do Sertão da Bahia. Agrotrópica (Brasil) 28(1):37-46.
SANTOS, M. A. L. et al. 2019. Ascomycota (lichenized and non-lichenized) on Syagrus coronata in the Caatinga biome: new and interesting records for Brazil and South America. Mycotaxon 134:737.

SEAWARD, M. R. D. 2008. Environmental role of lichens. In Lichen Biology (Nash III, T.H, ed.). Cambridge University Press, Cambridge. pp.274298.

SILVA, H. P. B. 2006. Radiossensibilidade gama de Cladonia substellata Vainio (líquen) e o conseqüente efeito sobre rochas calcárias. Dissertação de Mestrado. Universidade Federal de Pernambuco. CTG. Tecnologias Energéticas e Nucleares, Recife, PE. 45p.

SPIELMANN, A. A.; MARCELLI, M. P. 2008. Parmeliaceae (Ascomycota liquenizados) nos barrancos e peraus da encosta da Serra Geral, Vale do Rio Pardo, Rio Grande do Sul Brazil. I. Introduction and Key to Genus. Iheringia (Série Botânica) 63(1):159-169.

SPECIES FUNGORUM. Database. Available in: $<$ www.speciesfungorum.org $>$ Accessed on 31 march 2020.

STAIGER, B. 2005. How to arrange the diversity of a tropical lichen family? Archives des S c i e n c e s 58:53-62. 